\title{
DOI: https://doi.org/10.24297/jaa.v10i0.8282
}

\section{The Stimulating Effects of Imazalil and Carbendazim Fungicides on In Vitro Propagation and Ex Situ Conservation of The Medicinal Balkan Range-Restricted Sideritis Raeseri Boiss \& Heldr. Subsp. Raeseri}

\author{
Virginia Sarropoulou*, Eleni Maloupa
}

Hellenic Agricultural Organization (HAO) - DEMETER, Institute of Plant Breeding and Genetic Resources, Laboratory of Protection and Evaluation of Native and Floricultural Species, Balkan Botanic Garden of Kroussia,

P.C. 57001 Thermi, Thessaloniki, P.O. Box 60458, Greece

vsarrop@gmail.com

\begin{abstract}
Sideritis raeseri Boiss \& Heldr. subsp. raeseri, known in Greece as Mountain tea of Parnassus or Velouchi is a range restricted medicinal plant of the Balkan peninsula. Conventional propagation methods did not allow the mass production of plant material in a short period of time due to both low seed germination rate and rooting of cuttings. Therefore, the aim of this study was to establish a reliable, reproducible and efficient regeneration protocol for mass and large-scale micropropagation, germplasm and ex situ conservation of S. raeseri Boiss \& Heldr. using Imazalil and Carbendazim fungicides. After 9 weeks, 2.5-10 mg/l Imazalil stimulated root length by $1 \mathrm{~cm}$ but diminished root number and rooting percentage. Optimum shoot number (5.58), shoot length (24.91 $\mathrm{mm}$ ), shoot multiplication (100\%), root number (20.63) and rooting (66.67\%) were recorded with $0.5 \mathrm{mg} / \mathrm{l} \mathrm{kinetin}$ $(\mathrm{KN})+0.05 \mathrm{mg} / \mathrm{l} \alpha$-napthaleneacetic acid (NAA) (Imazalil-free). After $4 \frac{1}{12}$ weeks, $1 \mathrm{mg} / \mathrm{l}$ Carbendazim $+0.5 \mathrm{mg} / \mathrm{l}$ 6 -benzyladenine (BA) yielded 5.77 shoots/explant, $16.1 \mathrm{~mm}$ shoot length and $100 \%$ shoot multiplication. However, Carbendazim did not result in rooting. The ex vitro survival percentage of rooted shoot-tip explants derived from Imazalil experiment was 95\%. Carbendazim proved useful in shoot proliferarion and Imazalil in root elongation of S. raeseri Boiss \& Heldr. subsp. raeseri micropropagation system.
\end{abstract}

Indexing terms/Keywords: benzymidazoles, carbendazim, fungicides, mountain tea of Parnassus or Velouchi, imazalil, imidazoles, micropropagation, Sideritis raeseri Boiss. \& Heldr. subsp. raeseri, vitrification.

\section{Introduction}

Sideritis L. (Family Lamiaceae) comprises approximately 150 species of annuals and perennials distributed throughout North Africa, the Iberian Peninsula, the Mediterranean countries, and the Middle East region [1]. In Greece, S. raeseri Boiss. \& Heldr. (Mountain tea of Velouchi or Parnassus) is distributed in central, north-central and northern parts of the country (typically in the range of Pindos) or in neighbouring areas with Albania and the FYR of Macedonia according to Strid and Kit Tan [2]. S. raeseri L. is a perennial herb of up to $40 \mathrm{~cm}$, which self-sows in Parnassus, Timfristos (Velouchi) and other mountains of Aetolia, Doris and Fthiotida [3]. Aerial flowering parts of plants from Sideritis genus are known as "mountain tea," which is widely used in Mediterranean folk medicine as a very popular tea because of its anti-inflammatory [4], carminative, analgesic, antitussive, stomachic, and antimicrobial properties [5].

The application of fungicides in in vitro culture has shown that some of these substances may exhibit organogenic and morphogenic effects on in vitro plants. Thus, it has been discovered that the imidazole fungicides, such as imazalil either intensify the effect of exogenous cytokinins or inhibit biosynthesis of the gibberellic acid. A number of interesting side effects of the imidazole fungicide Imazalil can be observed in diverse tissue cultured plant species, i.e. excessive shoot formation in Araceae, inhibition of bushiness in Gerbera, restoration of normal embryo development in Citrus and histogenic instability of Ficus benjamina L. (Moraceae) chimeras [6]. When screening fungicides as potential tissue culture medium additives to control fungal development, it was found that the imidazole fungicide Imazalil exuberantly enhanced the shoot (bud)-inducing effect of BA in Spathiphyllum floribundum. On cytokinin-free medium imazalil did not induce buds [7]. Since the 
past decade, some azole derivatives, such as imazalil have been found promising to enhance the shoot inducing capacity of different cytokinins, including TDZ. According to Werbrouck and Debergh [8], TDZ mediated shoot proliferation improved by the inclusion of Imazalil in S. floribundum culture.

Bavistin is a systemic fungicide that belongs to benzimidazole family containing $50 \%$ WP carbendazim. Benzimidazole is a group of organic fungicides with systemic action that are extensively used in agriculture [9]. It has been reported that the molecular structure of methyl benzimidazole carbonate has some resemblance to cytokinins based on adenine [10], showing strong cytokinin-like activity in direct shoot regeneration. Earlier studies have shown that bavistin enhances differentiation of roots and shoots in calli derived from carrot segment ${ }^{[10]}$. In addition, the shoot regeneration promoting activity of bavistin resulted in increased biosynthesis of endogenous cytokinins within the cultured explants [11].

Plant tissue culture (PTC) offers a viable alternative method of propagation. It is used widely in the conservation of rare, endangered and medicinal plants and also commercial propagation. PTC constitutes a way to maintain available competent explants and free from contamination for use in vitro propagation and genetic transformation, besides being highly convenient for conservation of in vitro germplasm and cryopreservation [12]. PTC in turn is the only way to sustain the large-scale farming of medicinal plants, as this is the only technique to produce plants of high and uniform quality in large quantity from any part of the plant in any season [13].

Sideritis plants in the wild are sexually and asexually propagated [14]. Micropropagation was considered necessary for $S$. raeseri bulk vegetative propagation as the nature of the plant is such that does not give a large number of cuttings. The biggest problem is observed during rooting and acclimatization of the plantlets produced. At the same time, it will be the first results obtained with Sideritis spp. species using fungicides as micropropagation enhancing agents. Aiming at the improvement and advancement of shoot and root direct regeneration in vitro and bearing in mind the activity of imidazole and benzymidazole fungicides, all these aspects orientated us towards discovering their effect on in vitro shoot multiplication and rooting by developing a large-scale propagation protocol through direct plant regeneration using shoot tip explants. Therefore, the obtained results of this study and the final established micropropagation protocol for $S$. raeseri are going to be novel and of sufficient biotechnological importance.

\section{Materials and methods}

\section{Plant material and culture conditions}

The experimental material was shoot tip explants from previous S. raeseri in vitro cultures. For the initial establishment of the plant material in vitro, apex meristems were cut and removed from the mother plants maintained in a peat: perlite (1:1) substrate in pots under unheated-greenhouse conditions. For the disinfection of the collected plant material, shoot tips were soaked in $70 \%$ ethanol for 1 min followed by $2 \% \mathrm{NaOCl}$ solution for $15 \mathrm{~min}$ under continuous stirring. The successfully established explants were sub-cultured every 4 weeks until a sufficient amount of plant material to be concentrated. Two experiments were conducted. The nutrient medium used was the MS [15]. The pH of the medium in both experiments was adjusted to 5.8 before adding the gelling agent and afterwards the medium was sterilized at $121^{\circ} \mathrm{C}$ for $20 \mathrm{~min}$. For the experiment, shoot tip explants (1-2.5 cm, long) were transferred into Magenta vessels (Baby food jars, $62.4 \mathrm{~mm} \times 95.8 \mathrm{~mm}, 200 \mathrm{ml}$ ) containing $35 \mathrm{ml}$ of MS culture medium. All cultures were maintained in a growth chamber. The chamber was programmed to maintain a 16 -h light duration $\left(40 \mu \mathrm{mol} / \mathrm{m}^{2} / \mathrm{s}\right)$ supplied by cool white fluorescent lamps and a constant temperature of $22 \pm 2{ }^{\circ} \mathrm{C}$.

\section{Experiment 1: Effect of Imazalil on micropropagation of S. raeseri}

Imazalil (Fluka, PESTANAL ${ }^{\circledR}$, analytical standard) was applied exogenously at 5 concentrations $(0,1,2.5,5,10$ $\mathrm{mg} / \mathrm{l}$ ) in combination with $0.5 \mathrm{mg} / \mathrm{l} \mathrm{KN}$ (Sigma-Aldrich) and $0.05 \mathrm{mg} / \mathrm{l} \mathrm{NAA} \mathrm{(Sigma-Aldrich).} \mathrm{The} \mathrm{MS} \mathrm{culture}$ medium was supplemented with $30 \mathrm{~g} / \mathrm{l}$ sucrose (Duchefa) and $8 \mathrm{~g} / \mathrm{l}$ agar (Sigma-Aldrich) as a gelling agent. The experiment included 5 treatments with 12 replications (explants)/treatment and 4 shoot tip explants in each 
vessel. After 9 weeks of culture, measurements were taken regarding shoot number/explant, shoot length ( $\mathrm{mm}$ ), shoot multiplication percentage (\%), root number/rooted microcutting, root length $(\mathrm{mm})$, rooting percentage (\%), callus formation percentage (\%), vitrification and necrosis percentages (\%).

\section{Experiment 2: Effect of Carbendazim on micropropagation of S. raeseri}

Carbendazim (97\%, Sigma-Aldrich) was applied exogenously at 10 concentrations $(0,1,2.5,5,10,25,50,100$, $200,400 \mathrm{mg} / \mathrm{l}$ ) in combination with $0.5 \mathrm{mg} / \mathrm{l} \mathrm{BA}$ (Sigma-Aldrich). The culture medium was supplemented with $30 \mathrm{~g} / \mathrm{l}$ sucrose (Duchefa) and $3 \mathrm{~g} / \mathrm{l}$ Gelrite (Duchefa) as a gelling agent. The experiment included 10 treatments with 15 replications/treatment and 3 shoot tip explants in each vessel. After $4 \frac{1}{2}$ weeks of culture, data were recorded in terms of shoot number/explant, shoot length $(\mathrm{mm})$ and percentages (\%) of shoot multiplication, callus formation and vitrification.

\section{Ex vitro acclimatization of in vitro rooted plantlets}

Plantlets with well-developed shoots and roots were removed from the glass test tubes, washed thoroughly with tap water and transferred to an enriched peat (Terrahum): perlite (Perflor) $(1: 1 \mathrm{v} / \mathrm{v})$ soil substrate. The rooted microplantlets were transferred to multi-point discs. Then, these trays were placed in a nylon table bench tunnel with adjustable relative humidity or misting system, initially, in the first week with $65-72 \%$ relative humidity and the second week with 55-62\%. After two weeks the trays with the plants were transferred to one of the benches of the greenhouse ( $50 \pm 5 \%$ relative humidity) for two more weeks, wherein watered by sprinkling. After this period, the plants were transplanted into pots of $0.5 \mathrm{~L}$, transferred to the nursery outside greenhouse, where the acclimatization of the plants was completed. After 8 weeks from transplantation, the adjusted plants were transferred to pots of larger capacity, $1.5 \mathrm{~L}$, filled with enriched white peat moss (TS2, Clammann): perlite (Perflor): sand (2:2:0.5 v/v) soil substrate and maintained in the greenhouse. Finally, after 12 weeks from the initial transition of the in vitro rooted plantlets to the ex vitro environment, their survival percentage was recorded.

\section{Statistical analysis}

The experiment was completely randomized and analysed by ANOVA (Analysis of Variance) using the statistical program SPSS 17.0 (SPSS Inc., Illinois, New York, USA) at $\mathrm{P} \leq 0.05$, according to Duncan's multiple range test \pm Standard Error (S.E.) in order significant differences among the treatments to be established.

\section{Results and discussion}

\section{Experiment 1: Effect of Imazalil on micropropagation of S. raeseri}

In the current study employing S. raeseri, imazalil (1-10 mg/l) significantly reduced shoot number/explant from 5.58 (control) to $2.17-3$ as well as shoot multiplication percentage by half, from $100 \%$ in the control treatment to $41.67-58.33 \%$. Moreover, Imazalil at $10 \mathrm{mg} / \mathrm{l}$ caused $1 \mathrm{~cm}$ - decrease in shoot length (Table 1). Therefore, in S. raeseri Boiss \& Heldr, Imazalil exerted an inhibitory effect on shoot regeneration. On the contrary, Imazalil improved the efficacy of TDZ in S. floribundum [8] and this enhancing effect of Imazalil was attributed to its effect on changing the metabolism of exogenously applied cytokinins. Imazalil was also reported to have an inhibitory effect on cytokinin degrading enzymes [7, 16]. In the present study with $S$. raeseri, shoot number/explant (5.58), shoot length $(24.91 \mathrm{~mm})$ and shoot multiplication percentage (100\%) were maximum in the control combination treatment, $0.5 \mathrm{mg} / \mathrm{I} \mathrm{KN}+0.05 \mathrm{mg} / \mathrm{I} \mathrm{NAA}$, in devoid of Imazalil (Table 1 and Fig. 1a). On the other hand, in S. floribundum "Petite" Schott, multiple shoot induction was significantly increased by using Imazalil [7]. The stimulating effect of Imazalil in shoot proliferation of S. floribundum was recently stated to be due to inhibition of gibberellin (GA) biosynthesis [9]. Our results are also not in line with those reported by Tefera and Wannakrairoj [17] for korarima [Aframomum corrorima (Braun) Jansen] where $4 \mathrm{mg} / \mathrm{l}$ Imazalil +0.1 $\mathrm{mg} / \mathrm{l}$ BA raised shoot number. According to Wannakrairoj and Tefera [18], in Siam cardamom (Amomum krervanh Pierre ex Gagnep.), high axillary shoot proliferation and shoot growth rate were attained using a 
modified MS medium supplemented with $0.5 \mathrm{mg} / \mathrm{l}$ TDZ + $2 \mathrm{mg} / \mathrm{l}$ Imazalil. Therefore, the different response of studied $S$. raeseri to Imazalil treatments regarding shoot number seems to be genotype- and concentrationdependent.

Table 1. Effect of Imazalil concentration $(0-10 \mathrm{mg} / \mathrm{l})$ combined with $0.5 \mathrm{mg} / \mathrm{l} \mathrm{KN}$ and $0.05 \mathrm{mg} / \mathrm{l} \mathrm{NAA}$ on shoot number/ explant, shoot length ( $\mathrm{mm}$ ), shoot multiplication, vitrification and necrosis percentages (\%) in S. raeseri Boiss \& Heldr. subsp. raeseri.

\begin{tabular}{|c|c|c|c|c|c|}
\hline $\begin{array}{l}\text { Imazalil } \\
(\mathrm{mg} / \mathrm{l})\end{array}$ & $\begin{array}{c}\text { Shoot number } \\
\text { / explant }\end{array}$ & $\begin{array}{c}\text { Shoot length } \\
(\mathrm{mm})\end{array}$ & $\begin{array}{c}\text { Shoot multiplication } \\
\text { (\%) }\end{array}$ & $\begin{array}{c}\text { Vitrification } \\
\text { (\%) }\end{array}$ & $\begin{array}{c}\text { Necrosis } \\
\text { (\%) }\end{array}$ \\
\hline Control & $5.58 \pm 0.75 b$ & $24.91 \pm 2.41 b$ & $100 d$ & $16.67 \mathrm{c}$ & $0 \mathrm{a}$ \\
\hline 1 & $3.00 \pm 0.85 a$ & $25.99 \pm 4.89 b$ & $50 \mathrm{~b}$ & $25 d$ & $25 c$ \\
\hline 2.5 & $3.00 \pm 0.69 a$ & $17.15 \pm 1.39 \mathrm{ab}$ & $58.33 \mathrm{c}$ & $0 \mathrm{a}$ & $16.67 \mathrm{~b}$ \\
\hline 5 & $2.83 \pm 0.66 a$ & $21.18 \pm 3.16 a b$ & $58.33 \mathrm{c}$ & $8.33 \mathrm{~b}$ & $0 \mathrm{a}$ \\
\hline 10 & $2.17 \pm 0.60 a$ & $15.80 \pm 0.96 a$ & $41.67 \mathrm{a}$ & $0 \mathrm{a}$ & $0 \mathrm{a}$ \\
\hline$P$-values & $0.016^{*}$ & $0.060 \mathrm{~ns}$ & $0.000 * * *$ & $0.000^{* * *}$ & $0.000^{* \star *}$ \\
\hline
\end{tabular}

Means $(n=12) \pm$ standard error (S.E) with the same letter in each column are not statistically significant different from each other according to the Duncan's multiple range test at $P \leq 0.05$. Ns $P \geq 0.05 ;{ }^{*} P \leq 0.05 ;{ }^{* * \star P} \leq 0.001$.

Shoot multiplication percentage of $S$. raeseri was diminished due to Imazalil application. In contrast, the optimum shoot multiplication rate for korarima was obtained with $2 \mathrm{mg} / \mathrm{l}$ Imazalil + 0.5-0.75 mg/l TDZ [19]. Similarly, to our results, $12.5-50 \mu \mathrm{M}$ Imazalil did not affect to a large extent the multiplication rate in Gerbera 'Rosabella' (bushy) cultivar, however, higher Imazalil concentrations (100-200 $\mu \mathrm{M})$ led to cessation of shoot development [20]. In the Gerbera 'Sunset' (non-bushy) cultivar, Imazalil (12.5-25 $\mu \mathrm{M}$ ) did not affect the multiplication rate although $50 \mu \mathrm{M}$ Imazalil caused a slight, but significant reduction in shoot number. Imazalil at high concentrations (100-200 $\mu \mathrm{M}$ ) acted as a growth retardant leading to bushy shoots, complete inhibition of shoot development, necrotic symptoms and subsequent death of explants [20]. A decrease in shoot length of $S$. raeseri explants was recorded, approximately by $1 \mathrm{~cm}$ due to Imazalil application at $10 \mathrm{mg} / \mathrm{l}$, indicating that Imazalil at high concentrations is implicated in GA biosynthesis. As reviewed by Fletcher et al. [21], certain azole compounds, such as Imazalil interfere with the biosynthesis of gibberellins and influence plant morphogenesis, indicating their possible function as plant bio-regulators. The mode of action of Imazalil is unclear; it only induces shoots in the presence of exogenous cytokinins such as BA, indicating that Imazalil might alter BA metabolism or catabolism [6]. The percentage of vitrified S. raeseri explants was ranged between 0 and $25 \%$. Necrotic symptoms were observed to the $16.67-25 \%$ of the explants treated with 1 or $2.5 \mathrm{mg} / \mathrm{l}$ Imazalil whereas no necrosis occurred to the Imazalil-untreated explants and explants treated with 5 or $10 \mathrm{mg} / \mathrm{l}$ Imazalil (Table 1).

In this research study with $S$. raeseri microplants, Imazalil reduced root number from 20.63 in the control treatment (Fig. 1a) to 6.71-10 ( 2 to 3 times decrease) (Fig. 1b-1e). On the other hand, root length was enhanced (31.95-35.72 mm) when explants treated with 2.5-10 mg/l Imazalil (Table 2). 
Table 2. Effect of Imazalil concentration ( $0-10 \mathrm{mg} / \mathrm{l})$ combined with $0.5 \mathrm{mg} / \mathrm{l} \mathrm{KN}$ and $0.05 \mathrm{mg} / \mathrm{l} \mathrm{NAA}$ on root number/ rooted microcutting, root length $(\mathrm{mm})$, rooting and callus formation percentages (\%) in $\mathrm{S}$. raeseri Boiss \& Heldr. subsp. raeseri.

\begin{tabular}{ccccc}
\hline $\begin{array}{c}\text { Imazalil } \\
(\mathbf{m g} / \mathbf{l})\end{array}$ & $\begin{array}{c}\text { Root number/ rooted } \\
\text { microcutting }\end{array}$ & $\begin{array}{c}\text { Root length } \\
\mathbf{( m m})\end{array}$ & $\begin{array}{c}\text { Rooting } \\
\mathbf{( \% )}\end{array}$ & $\begin{array}{c}\text { Callus formation } \\
\mathbf{( \% )}\end{array}$ \\
\hline Control & $20.63 \pm 2.84 \mathrm{~b}$ & $23.87 \pm 1.32 \mathrm{a}$ & $66.67 \mathrm{c}$ & $100 \mathrm{~d}$ \\
\hline $\mathbf{1}$ & $9.29 \pm 0.97 \mathrm{a}$ & $22.07 \pm 2.06 \mathrm{a}$ & $66.67 \mathrm{c}$ & $100 \mathrm{~d}$ \\
\hline $\mathbf{2 . 5}$ & $6.71 \pm 0.64 \mathrm{a}$ & $31.95 \pm 3.47 \mathrm{~b}$ & $58.33 \mathrm{~b}$ & $25 \mathrm{a}$ \\
\hline $\mathbf{5}$ & $10.00 \pm 1.40 \mathrm{a}$ & $33.14 \pm 2.28 \mathrm{~b}$ & $58.33 \mathrm{~b}$ & $83.33 \mathrm{c}$ \\
\hline $\mathbf{1 0}$ & $8.50 \pm 0.55 \mathrm{a}$ & $35.72 \pm 2.09 \mathrm{~b}$ & $25 \mathrm{a}$ & $50 \mathrm{~b}$ \\
\hline $\boldsymbol{P}$-values & $0.000^{* * *}$ & $0.000^{* * *}$ & $0.000^{* * *}$ & $0.000^{* * *}$ \\
\hline
\end{tabular}

Means $(n=12) \pm$ standard error (S.E) with the same letter in each column are not statistically significant different from each other according to the Duncan's multiple range test at $P \leq 0.05$. ${ }^{* *} P \leq 0.001$.

In Korarima, root number and root length were decreased with increasing Imazalil concentration (0-4 mg/l) in devoid of cytokinins [17]. According to Werbrouck and Debergh [7], in S. floribundum when Imazalil (4 or 16 $\mathrm{mg} / \mathrm{l}$ ) was applied without BA, root number and root length were reduced, but no new shoots were developed. In this study, thus, $2.5-10 \mathrm{mg} / \mathrm{I}$ Imazalil even though promoted root elongation of $S$. raeseri shoot tip explants, however led to a simultaneous decrease in root number and rooting percentage. In particular, rooting (66.67\%) and callus formation (100\%) were highest in the control and in explants treated with $1 \mathrm{mg} / \mathrm{l}$ Imazalil. In addition, imazalil (2.5-10 mg/l) decreased callogenesis percentage of $S$. raeseri explants (Table 2). Similarly, in Gerbera 'Rosabella' (bushy) cultivar, Imazalil reduced callus formation [20]. 


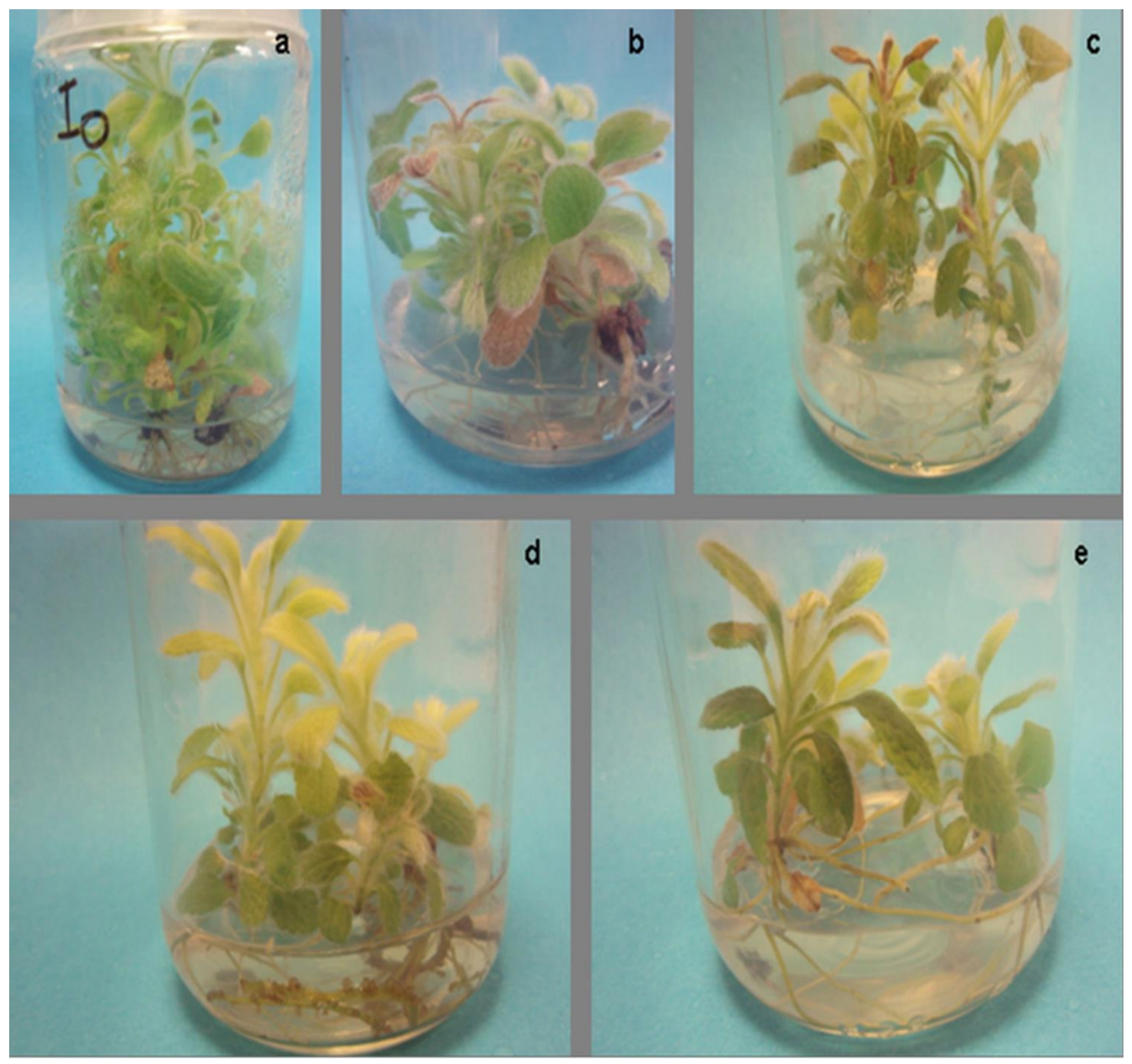

Fig. 1. Effect Imazalil concentration combined with $0.5 \mathrm{mg} / \mathrm{l} \mathrm{KN}+0.05 \mathrm{mg} / \mathrm{l} \mathrm{NAA}$ on micropropagation of $S$. raeseri Boiss \& Heldr. subsp. raeseri: (a) Control (Imazalil-free), (b) 1 mg/l, (c) $2.5 \mathrm{mg} / \mathrm{l}$, (d) $5 \mathrm{mg} / \mathrm{l}$, (e) $10 \mathrm{mg} / \mathrm{l}$ Imazalil.

In the current study, $95 \%$ ex vitro survival percentage of S. raeseri in vitro rooted explants originated from Imazalil experiment was recorded (Fig. 2). 


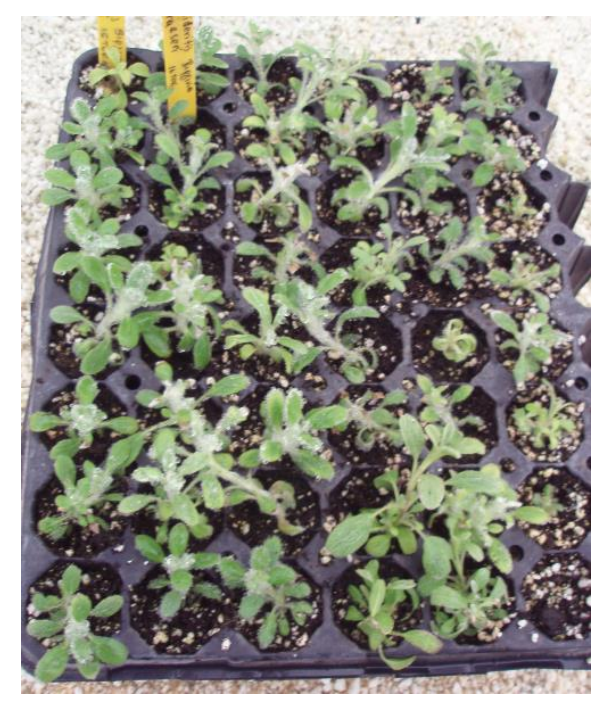

Fig. 2. Ex vitro acclimatization and hardening of rooted microcuttings derived from Imazalil-enriched and Imazalil-free culture media in the mist system under unheated greenhouse conditions.

\section{Experiment 2: Effect of Carbendazim on micropropagation of S. raeseri}

The combined effect $0.5 \mathrm{mg} / \mathrm{l} \mathrm{BA}+1 \mathrm{mg} / \mathrm{l}$ Carbendazim gave the best results with respect to the number of shoots/ explant (5.77), shoot length $(16.1 \mathrm{~mm})$ and shoot multiplication percentage (100\%) (Fig. 3b) compared to the control (0.5 mg/l BA, Carbendazim-free) (Table 3 and Fig. 3a). Carbendazim applied at $1 \mathrm{mg} / \mathrm{l}$ in combination with $0.5 \mathrm{mg} / \mathrm{l} \mathrm{BA}$ promoted in vitro shoot proliferation of $S$. raeseri explants in relation to BA alone, thus, Carbendazim showed cytokinin-like activity by enhancing the stimulatory effect of BA on shoot proliferation. In accordance to our findings in S. raeseri, the positive effect of bavistin (100-300 mg/l) on in vitro shoot regeneration has already been reported in several other plant species including Solanum viarum Dunal (Tropical Soda apple) [22], Centella asiatica (L.) Urban [23], Asclepias curassavica (L.) (Tropical milkweed) [24], peppermint (Mentha piperita L.) [25], Stevia rebaudiana [26] and Nepali's Kutki (Picrorhiza scrophulariiflora Pannell.) [27].

Table 3. Effect of Carbendazim concentration ( $0-400 \mathrm{mg} / \mathrm{l})$ combined with $0.5 \mathrm{mg} / \mathrm{l}$ BA on shoot number/ explant, shoot length $(\mathrm{mm})$, shoot multiplication percentage (\%), callus formation and vitrification percentages (\%) in S. raeseri Boiss \& Heldr. subsp. raeseri.

\begin{tabular}{|c|c|c|c|c|c|}
\hline $\begin{array}{c}\text { Carbendazim } \\
(\mathrm{mg} / \mathrm{l})\end{array}$ & $\begin{array}{c}\text { Shoot number } \\
\text { /explant }\end{array}$ & $\begin{array}{c}\text { Shoot length } \\
(\mathrm{mm})\end{array}$ & $\begin{array}{c}\text { Shoot } \\
\text { multiplication } \\
\text { percentage } \\
\text { (\%) }\end{array}$ & $\begin{array}{c}\text { Callus } \\
\text { formation } \\
\text { percentage } \\
(\%)\end{array}$ & $\begin{array}{c}\text { Vitrification } \\
\text { percentage } \\
\text { (\%) }\end{array}$ \\
\hline Control & $4.64 \pm 0.42 \mathrm{cde}$ & $12.17 \pm 0.79 \mathrm{ab}$ & $90.91 \mathrm{~d}$ & $100 \mathrm{f}$ & $18.18 \mathrm{~d}$ \\
\hline 1 & $5.77 \pm 0.74 \mathrm{e}$ & $16.10 \pm 0.72 c$ & $100 \mathrm{~g}$ & $100 \mathrm{f}$ & $0 \mathrm{a}$ \\
\hline 2.5 & $2.69 \pm 0.28 a b$ & $11.15 \pm 0.69 \mathrm{ab}$ & 76.92 bc & $92.31 \mathrm{e}$ & $76.92 \mathrm{~g}$ \\
\hline 5 & $2.86 \pm 0.32 \mathrm{ab}$ & $13.66 \pm 0.84 \mathrm{bc}$ & 92.86 ef & $78.57 \mathrm{c}$ & $14.29 \mathrm{c}$ \\
\hline 10 & $3.93 \pm 0.70 \mathrm{bcd}$ & $11.48 \pm 0.83 \mathrm{ab}$ & $86.67 \mathrm{e}$ & $66.67 \mathrm{~b}$ & $33.33 \mathrm{e}$ \\
\hline
\end{tabular}




\begin{tabular}{cccccc}
\hline $\mathbf{2 5}$ & $2.92 \pm 0.56 \mathrm{ab}$ & $16.10 \pm 1.28 \mathrm{c}$ & $75.00 \mathrm{~b}$ & $91.67 \mathrm{~d}$ & $8.33 \mathrm{a}$ \\
\hline $\mathbf{5 0}$ & $2.07 \pm 0.25 \mathrm{a}$ & $12.05 \pm 0.91 \mathrm{ab}$ & $64.29 \mathrm{a}$ & $57.14 \mathrm{a}$ & $42.86 \mathrm{f}$ \\
\hline $\mathbf{1 0 0}$ & $5.23 \pm 0.65 \mathrm{cde}$ & $9.67 \pm 0.62 \mathrm{a}$ & $92.31 \mathrm{ef}$ & $61.54 \mathrm{ab}$ & $23.08 \mathrm{~d}$ \\
\hline $\mathbf{2 0 0}$ & $3.82 \pm 0.60 \mathrm{bc}$ & $13.60 \pm 0.73 \mathrm{bc}$ & $81.82 \mathrm{bcd}$ & $54.55 \mathrm{a}$ & $0 \mathrm{a}$ \\
\hline $\mathbf{4 0 0}$ & $5.57 \pm 0.62 \mathrm{de}$ & $13.01 \pm 1.10 \mathrm{~b}$ & $81.82 \mathrm{bcd}$ & $92.86 \mathrm{e}$ & $0 \mathrm{a}$ \\
\hline P-values & $0.000^{\star * *}$ & $0.000^{* * *}$ & $0.000^{* * *}$ & $0.000^{* * *}$ & $0.000^{* * *}$
\end{tabular}

Means $(n=15) \pm$ standard error (S.E) with the same letter in each column are not statistically significant different from each other according to the Duncan's multiple range test at $P \leq 0.05$. ${ }^{* * *} P \leq 0.001$.

In the experiment with S. raeseri, $1 \mathrm{mg} / \mathrm{l}$ Carbendazim $+0.5 \mathrm{mg} / \mathrm{l} \mathrm{BA}$ resulted in 100\% shoot proliferation (Table 3). According to Baskaran and Jayabalan [28], TDZ, BA, bavistin or Carbendazim and NAA combinations positively influenced adventitious shoot regeneration of Psoralea corylifolia L. (Fabaceae). In S. raeseri, however, there was a decline in shoot multiplication percentage in the 10-50 mg/l Carbendazim concentration range (Table 3). In $S$. rebaudiana in vitro culture, $200 \mathrm{mg} / \mathrm{l}$ bavistin $+2 \mathrm{mg} / \mathrm{l} \mathrm{BA}$ decreased the frequency of axillary bud explants for regeneration when compared with the cultures containing only bavistin [26]. Regarding $S$. raeseri explants, 1$400 \mathrm{mg} / \mathrm{l}$ Carbendazim neither promoted nor inhibited shoot elongation (Table 3). On the other hand, in Cordyline terminalis and Prunus avium species, Carbendazim concentrations above $160 \mathrm{mg} / \mathrm{l}$ had a negative impact on the height of seedlings [29], while in the Indian medicinal herb B. monniera, $300 \mathrm{mg} / \mathrm{l}$ Carbendazim contributed to a remarkable elongation of the explants [30]. 


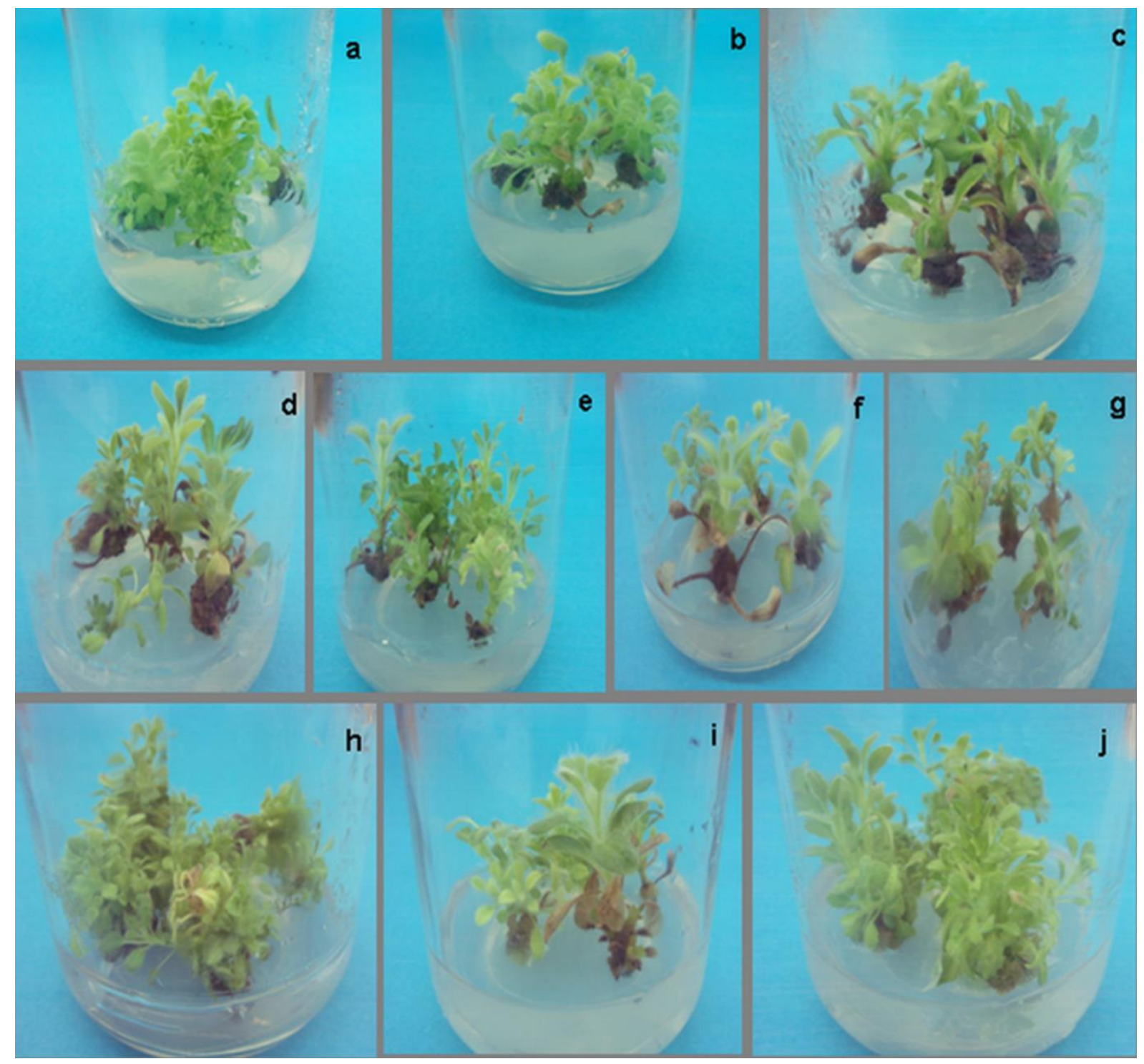

Fig. 3. Effect of Carbendazim concentration $(0-400 \mathrm{mg} / \mathrm{l})$ combined with $0.5 \mathrm{mg} / \mathrm{l}$ BA on in vitro shoot proliferation of S. raeseri Boiss \& Heldr. subsp. raeseri: (a) Control (Carbendazim-free), (b) $1 \mathrm{mg} / \mathrm{l}$, (c) $2.5 \mathrm{mg} / \mathrm{l}$, (d) $5 \mathrm{mg} / \mathrm{l}$, (e) $10 \mathrm{mg} / \mathrm{l}$, (f) $25 \mathrm{mg} / \mathrm{l}$, (g) $50 \mathrm{mg} / \mathrm{l}$, (h) $100 \mathrm{mg} / \mathrm{l}$, (i) $200 \mathrm{mg} / \mathrm{l}$, (j) $400 \mathrm{mg} / \mathrm{l} \mathrm{Carbendazim.}$

In this research study, S. raeseri shoot tip explants treated with 2.5-400 mg/l Carbendazim exhibited decreased callus induction percentages. Callogenesis was $100 \%$ in the control treatment, and with $1 \mathrm{mg} / \mathrm{l}$ Carbendazim (Table 3). According to Nandi et al. [31], in Taxus baccata ornamental plants, Carbendazim induced callogenesis (>90\%). In this experiment with S. raeseri, hyperhydricity symptoms were observed both in the control and in 2.5-100 mg/l Carbendazim treatments. Furthermore, no hyperhydricity symptoms were evident when explants were treated with 200 or $400 \mathrm{mg} / \mathrm{l}$ Carbendazim (Fig. 3i-3j). Instead, the vitrification problem was evident and more extensive in the case of the control (18.18\%) and less severe with 2.5-100 mg/l Carbendazim (8.33-76.92\%) (Fig. 3c-3h). However, there were no signs of vitrification in S. raeseri microshootlets treated with $1 \mathrm{mg} / \mathrm{l}$ or 200 400 mg/l Carbendazim (Table 3). In Nepali's Kutki microplants, no vitrification was observed with 50-100 mg/l bavistin, nevertheless, vitrification was increased about $49.2 \%$ when $400 \mathrm{mg} / \mathrm{l}$ bavistin were used [27]. Carbendazim did not affect shoot proliferation of $S$. raeseri explants adversely and did not lead to the appearance of necrotic symptoms. 


\section{Conclusions}

From the results obtained it is evident that the imidazole fungicide Imazalil cannot be used in tissue culture systems as a promoting shoot proliferation agent, however, its use is recommended only for enhancing root elongation of $S$. raeseri shoot tip explants. The use of the benzymidazole fungicide Carbendazim may be useful as a media supplement to develop efficient protocols as it eliminated the contaminating microorganisms and subsequently favoured in vitro shoot regeneration of $S$. raeseri explants. Because of unrestricted exploitation of this useful medicinal plant, its population is fast receding from the natural habitat, therefore, effective conservation methods are required for its protection from extinction. This protocol can be successfully used for clonal micropropagation of $S$. raeseri Boiss \& Heldr. subsp. raeseri in a commercial scale at short time rather than natural conditions and in genetic transformations. The study is useful in establishing technological improvement in S. raeseri by genetic engineering and transferring new improved quantitative and qualitative traits in several mountain tea species of Sideritis genus.

\section{Acknowledgements}

This research project was funded under the Action "Research \& Technology Development Innovation projects (AgroETAK)", MIS 453350, in the framework of the Operational Program "Human Resources Development". It was co-funded by the European Social Fund and by National Resources through the National Strategic Reference Framework 2007-2013 (NSRF 2007-2013) coordinated by the Hellenic Agricultural Organisation "DEMETER" (Institute of Plant Breeding and Genetic Resources/Scientific supervisor: Dr Eleni Maloupa).

\section{Conflict of Interest}

The authors declare that there is no conflict of interest regarding the publication of this article.

\section{References}

1. Barber JC, Francisco-Ortega J, Santos-Guerra A, Turner KG, Hansen RK. Origin of Macaronesian Sideritis L. (Lamioideae, Lamiaceae) inferred from nuclear and chloroplast sequence datasets. Mol. Phylogen. Evol. 2002; 23: 293-306.

2. Strid A, Tan T. Mountain flora of Greece. Vol. 2. Edinburgh: Edinburgh University Press, 1991; 974.

3. Goliaris A. Cultivation of the mountain tea. Ministry of Agriculture-Agrotica, 1984; 16: 29-31.

4. Aboutabl E, Nassar M, Elsakhawy F, Maklad Y, Osman A, El-Khrisy E. Phytochemical and pharmacological studies on Sideritis taurica Stephan ex Wild. J. Ethnopharmacol. 2002; 82: 177-184.

5. Gabrieli C, Kefalas P, Kokkalou E. Antioxidant activity of flavonoids from Sideritis raeseri. J. Ethnopharmacol. 2005; 96: 423-428.

6. Werbrouck SPO, Dhuyvetter H, Pérez RM, Topoonyanont N, Debergh PC. Plant propagation in vitro: hormonal interactions. Acta Hortic. 2001; 560: 377-381.

7. Werbrouck SPO, Debergh PC. Imazalil enhances the shoot inducing effect of benzyladenine in Spathiphyllum floribundum Schott. J. Plant Growth Regul. 1995; 14: 105-107.

8. Werbrouck SPO, Debergh PC. Imadizole fungicides and paclobutrazol enhance cytokinin-induced adventitious shoot proliferation in Araceae. J. Plant Growth Regul. 1996; 15: 81-85.

9. Delp CJ. Benzimidazole and related fungicides. In Modern selective fungicides, 2nd edn, Lyr H. (ed), Jena: Gustav Fisher Verlag, 1987; 291-303.

10. Tripathi RK, Ram S. Induction of growth and differentiation of carrot callus cultures by carbendazim and benzimidazole. Indian J. Exp Biol. 1982; 20: 674-677. 
11. Garcia PC, Rivero RM, Ruiz JM, Romero L. The role of fungicides in the physiology of higher plants: Implications for defence responses. Bot. Rev. 2003; 69: 162-172.

12. Rout GR, Samantaray S, Das P. In vitro manipulation and propagation of medicinal plants. Biotechnol. Adv. 2000; 18(2): 91-120.

13. Hassan AKMS, Roy SK. Micropropagation of Gloriosa superba L. through high frequency shoots proliferation. Plant Tiss. Cult. Biotechnol. 2005; 15: 67-74.

14. Goliaris A, Roupakias D. Yield performance of interspecific F1 hybrids of the Greek mountain tea (Sideritis spp. L.). Plant Breed. 1997; 166: 493-497.

15. Murashige T, Skoog F. A revised medium for rapid growth and bioassays with tobacco tissue cultures. Physiol. Plant. 1962; 15: 473-497.

16. Werbrouck SPO, Debergh PC. Possible role of gibberellins in the interaction between cytokinins and pesticides. Acta Hortic. 1997; 447: 59-62.

17. Tefera W, Wannakrairoj S. A micropropagation method for korarima [Aframomum corrorima (Braun) Jansen]. ScienceAsia, 2004; 30: 1-7.

18. Wannakrairoj $\mathrm{S}$, Tefera W. Thidiazuron and other plant bioregulators for axenic culture of Siam cardamom (Amomum krervanh Pierre ex Gagnep.). Kasetsart J. (Nat. Sci.) 2012; 46: 335-345.

19. Tefera W, Wannakrairoj S. Synergistic effects of some plant growth regulators on in vitro shoot proliferation of korarima [Aframomum corrorima (Braun) Jansen]. Afr. J. Biotechnol. 2006; 5: 1894-1901.

20. Topoonyanont N, Debergh PC. Reducing bushiness in micropropagated Gerbera. Plant Cell Tiss. Organ Cult. 2001; 67: 133-144.

21. Fletcher RA, Gilley A, Sankhala N, Davis TD. Triazoles as growth regulators and stress protectants. Hort. Rev. 2000; 24: 55-138.

22. Mahadev MD, Panathula CS, Naidu CV. Influence of bavistin, cefotoxime, kanamycin and silver thiosulphate on plant regeneration of Solanum viarum (Dunal) - An important anticancer medicinal plant. Am. J. Plant Sci. 2014; 5: 403-408.

23. Panathula CS, Mahadev MDN, Naidu CV. The stimulatory effects of the antimicrobial agents bavistin, cefotaxime and kanamycin on in vitro plant regeneration of Centella asiatica (L.) - An important antijaundice medicinal plant. Am. J. Plant Sci. 2014; 5: 279-285.

24. Reddy SH, Chakravarthi C, Chandrashekara KN, Naidu CV. Influence of bavistin and silver thiosulphate on in vitro regeneration of Asclepias curassavica (L.) using nodal explants. Am. J. Plant Sci. 2012; 3: 941-946.

25. Sujana P, Naidu CV. Influence of bavistin, cefotaxime, kanamycin and silver thiosulphate on plant regeneration of Mentha piperita (L.) - An important multipurpose medicinal plant. J. Phytol. 2011; 3: 3640.

26. Preethi D, Sridhar TM, Naidu CV. Effect of bavistin and silver thiosulphate on in vitro plant regeneration of Stevia rebaudiana. J. Phytol. 2011; 3: 74-77.

27. Bantawa P, Roy OS, Ghosh P, Mondal TK. Effect of bavistin and adenine sulphate on in vitro shoot multiplication of Picrorhiza scrophulariiflora Pennell.: An endangered medicinal plant of Indo-China Himalayan regions. 2009; Plant Tiss. Cult. \& Biotechnol. 19: 237-245.

28. Baskaran $\mathrm{P}$, Jayabalan N. An improved protocol for adventitious shoot regeneration and plant formation in Psoralea corylifolia L. 2009; Sci. Hortic. 123: 283-286.

29. Debergh PC, Coster G, Steurbaut W. Carbendazim as an alternative plant growth regulator in tissue culture systems. 1993; In Vitro Cell. Develop. Biol.-Plant 29: 89-91.

30. Tiwari V, Tiwari KN, Sing BD. Shoot bud regeneration from different explants of Bacopa monniera (L.) Wettst. by trimethoprim and bavistin. Plant Cell Rep. 2006; 25: 629-635. 
31. Nandi SK, Palni LMS, Rikkari HC. Chemical induction of adventitious root formation in Taxus baccata cuttings. Plant Growth Regul. 1996; 19: 117-122. 